\title{
PENGEMBANGAN LEMBAR KERJA PESERTA DIDIK BERDASARKAN IDENTIFIKASI TUMBUHAN OBAT DESA CAHAYA NEGERI KABUPATEN REJANG LEBONG
}

\author{
Satria Nugeraha $\mathrm{M}^{1^{*}}$, Yennita ${ }^{1}$, Ariefa Primair Yani ${ }^{1}$ \\ ${ }^{1}$ Program Studi Pendidikan Biologi, Fakultas Keguruan dan Ilmu Pendidikan, Universitas Bengkulu \\ Email : nmsatria@gmail.com
}

\begin{abstract}
Abstrak
Penelitian ini bertujuan untuk mengetahui kelayakan lembar kerja peserta didik (LKPD) yang dikembangkan berdasarkan studi identifikasi obat desa Cahaya Negeri Kabupaten Rejang Lebong berdasarkan uji validasi LKPD dan uji keterbacaan pada peserta didik kelas X MIA 2 SMAN 09 Rejang Lebong. Materi pelajaran yang dikembangkan dalam LKPD ini adalah materi keanekaragaman hayati Sub Bab manfaat keanekaragaman hayati sebagai bahan obat. Penelitian menggunakan model pengembangan Borg and Gall yang telah dimodifikasi yaitu potensi dan masalah, pengumpulan data, desain produk LKPD, validasi desain, revisi desain dan uji keterbacaan. Instrumen yang digunakan yaitu lembar observasi lapangan, lembar wawancara, lembar angket validasi. Berdasarkan penelitian diperoleh data bahwa terdapat 74 jenis tanaman obat yang terbagi menjadi 38 famili tanaman. Penggunaan LKPD dalam pembelajaran dikatakan "Layak" dengan hasil validasi rata-rata $92 \%$ dengan kriteria "sangat valid" dan hasil uji keterbacaan mendapatkan rata-rata nilai $95 \%$ dengan kriteria "sangat layak". Dapat disimpulkan bahwa LKPD dengan judul keanekaragaman jenis tumbuhan obat layak digunakan dalam pembelajaran.
\end{abstract}

Kata Kunci : LKPD, Tumbuhan Obat, Uji Keterbacaan

\begin{abstract}
This research aims to determine Student Worksheet (LKPD) which was developed based on the identification study of medicinal plants in the village of Cahaya Negeri Rejang Lebong Regency based on the Student Worksheet (LKPD) validation test and readability test on students of tenth grade of MIA 2 of SMAN 09 Rejang Lebong with the material in this study namely biodiversity material Sub chapter of the benefits of biodiversity as medicinal ingredients. This type of research is research and development (R \& D) with the main steps of Borg and Gall that have been modified namely potential and problems, data collection, LKPD product design, design validation, design revision and readability test. The instruments used were field observation sheets, interview sheets, validation questionnaire sheets. Based on the research, 74 types of medicinal plants were divided into 38 plant families. The use of LKPD in learning is said to be "Worthy" with the results of validation getting an average score of $92 \%$ with the criteria "very valid" and the readability test results getting an average score of $95 \%$ with the criteria " very feasible ". It can be concluded that the worksheet with the title of diversity of medicinal plants "Eligible' is used in learning.
\end{abstract}

Keyword : Student Worksheet, Medicinal Plants, Readability Test 


\section{PENDAHULUAN}

Guru dituntut memiliki kreativitas yang tinggi dalam mengajar dan membuat bahan ajar. Menurut Prastowo (2011) bahan ajar merupakan segala bahan (baik informasi, alat, maupun teks) yang disusun secara sistematis yang digunakan dalam proses pembelajaran. Salah satu bentuk dari bahan ajar ini adalah bahan ajar cetak yang berupa lembar kegiatan peserta didik (LKPD).

LKPD adalah salah satu sumber belajar yang dapat dikembangkan oleh guru sebagai fasilitator dalam kegiatan pembelajaran (Majid,2013). LKPD ini umumnya dibeli bukan dibuat oleh guru. Padahal LKPD sebenarnya bisa dibuat sendiri oleh guru yang bersangkutan., LKPD dapat dibuat lebih kontekstual sesuai dengan kondisi sekolah maupun lingkungan sosial peserta didik (Prastowo, 2011).

Mata pelajaran Biologi merupakan bagian dari pembelajaran sains. Dalam mempelajari hal ini, konsep-konsep tidak hanya diperoleh oleh siswa secara instan dari guru maupun buku-buku sebagai sumber belajar, melainkan dapat diperoleh sendiri melalui kegiatan ilmiah atau proses sains. Proses sains ini dapat dilakukan dengan kegiatan pengamatan langsung pada morfologi tumbuhan obat. Tumbuhan obat sudah sangat dikenal berkhasiat dalam menanggulangi berbagai kesehatan. Pengetahuan tentang tumbuhan yang berkhasiat obat diperoleh berdasarkan pengalaman dan keterampilan yang turun-temurun dari nenek moyang dari generasi ke generasi selanjutnya (Kumalasari, 2006).

Tumbuhan obat merupakan bahan baku dalam pembuatan obat. Pengobatan tradisional ini merupakan bagian dari sistem budaya masyarakat yang potensi manfaatnya sangat besar dalam pembangunan kesehatan masyarakat. Pemanfaatan obat tradisional untuk pengobatan sendiri (self care) cenderung meningkat. Pada tahun 1999 baru mencapai 20,5 persen. Sementara itu menurut hasil Survei Sosial Ekonomi Nasional (Susenas) di tahun 2001 angkanya meningkat menjadi 31,7 persen dan $9,8 \%$ lebih memilih cara pengobatan tradisional lainnya. Secara internasional obat-obat tradisional yang menggunakan bahan-bahan dari tumbuhan (herbal medicine) lebih maju (Situmorang dkk, 2018), tumbuhan obat ini juga menjadi kepercayaan masyarakat Desa Cahaya Negeri sebagai alternatif pertolongan pertama pada saat sakit.

Masyarakat Desa Cahaya Negeri memperoleh tumbuhan obat dengan berbagai cara, antara lain sudah tumbuh liar di desa tersebut, membudidayakannya sendiri, meminta dari pekarangan rumah warga, membeli ataupun mendapatkannya dari luar desa. Selain itu, masyarakat di Desa Cahaya Negeri juga masih banyak memanfaatkan jasa battra dalam mengobati suatu penyakit. Dalam pengobatan alternatif yang dilakukan, battra masih memanfaatkan tumbuhan obat dalam mengobati suatu penyakit. Saat ini, di Kecamatan Sindang Kelingi telah berdiri Puskesmas lengkap dengan tenaga medis dan obat-obatan kimia. Namun, Puskesmas tersebut jaraknya cukup jauh dari desa tersebut. Puskesmas tersebut terletak di dekat Kantor Camat Sindang Kelingi yaitu di Desa Beringin Tiga yang jaraknya 5-6 km dari Desa Cahaya Negeri. Dengan kondisi seperti itu, hal ini mendorong masyarakat untuk mencari berbagai alternatif pengobatan tradisional.

Kelebihan tumbuhan obat menurut Herbie (2015) yaitu mempunyai beberapa kelebihan dibandingkan dengan 
obat kimia modern, diantaranya adalah tumbuhan obat memiliki harga yang lebih terjangkau dibandingkan dengan obat kimia modern, tumbuhan obat memiliki efek samping yang relatif lebih sedikit bahkan ada yang sama sekali tidak menimbulkan efek samping jika digunakan secara tepat, tumbuhan obat tidak hanya memperbaiki beberapa sistem tubuh tapi memperbaiki keseluruhan sistem tubuh, hal itulah yang menjadi pedoman battra desa untuk menggunakan tumbuhan herbal sebagai obat.

Ada 3 hal yan bisa dijadikan alasan tumbuhan dapat dikatakan sebagai obat yaitu : (a) Tumbuhan atau bagian tumbuhan dapat memperkuat fungsi organ tubuh, (b) Tumbuhan atau bagian tumbuhandapat menyingkirkan racun atau penyakit, (c) Tumbuhan atau bagian dapat membangun sistem kekebalan tubuh (Hidayat dkk, 2008).

Jenis tumbuhan obat yang ditemukan di desa Cahaya Negeri dapat dijadikan sebagai bahan/objek praktikum siswa dalam melakukan proses sains di sekolah. Dalam menunjang proses sains tersebut, dibuatlah sebuah alat bantu dalam pembelajaran Biologi berupa LKPD berbasis riset (hasil penelitian) yang sebelumnya divalidasi oleh dosen dan guru. Uji keterbacaan dalam penelitian ini dilakukan di SMA 09 Rejang Lebong. Hasil identifikasi tumbuhan yang ditemukan di desa cahaya negeri kemudian dijadikan sebagai materi dalam LKPD untuk Kompetensi Dasar (KD) 3.2 Mendeskripsikan konsep keanekaragaman gen, jenis, ekosistem, melalui kegiatan pengamatan.

\section{METODE}

Penelitian ini merupakan jenis penelitian dan pengembangan (Research and Development) yang dilakukan dengan menggunakan model pengembangan
(Sugiyono, 2009). Penelitian ini dilaksanakan selama 3 bulan yaitu dari bulan Febuari-April 2019. Penelitian ini dilakukan di Desa Cahaya Negeri Kabupaten Rejang Lebong Provinsi Bengkulu. Subjek penelitian ini adalah peserta didik kelas X IPA SMAN 09 Rejang Lebong.

Untuk validasi LKPD dilakukan oleh 3 orang validator, yang terdiri dari 1 orang dosen biologi dan 2 orang guru biologi. Aspek yang dinilai meliputi materi, desain dan kepraktisan. Teknik pengumpulan data pada penelitian ini dilakukan dengan angket yang terdiri dari angket uji kelayakan untuk validator (ahli materi, ahli media dan ahli praktisi/guru) dan angket keterbacaan LKPD untuk peserta didik.

Data uji validasi LKPD oleh 3 orang validator dan uji keterbacaan yang terkumpul dianalisis secara deskriptif kuantitatif, kemudian diubah ke dalam bentuk persentase kelayakan dengan rumus:

Persentase $=\frac{\text { Jumlah skor lembar validasi }}{\text { Skor maksimal }} \times 100 \%$

(Riduwan, 2015)

Hasil analisis data dari uji validasi LKPD yang berupa persentase tersebut kemudian diinterpretasikan dengan menggunakan panduan tabel kriteria penilaian hasil validasi LKPD yang dapat dilihat pada Tabel 1. Sedangkan, hasil analisis data dari uji keterbacaan LKPD dari peserta didik diinterpretasikan dengan menggunakan panduan kriteria penilaian uji keterbacaan LKPD yang dapat dilihat pad Tabel 2.

Tabel 1. Kriteria Penilaian Hasil Validasi LKPD

\begin{tabular}{cc}
\hline Persentase & Kriteria \\
\hline $81-100$ & Sangat valid \\
$61-80$ & Valid \\
$41-60$ & Cukup valid
\end{tabular}




$\frac{21-40 \quad \text { Kurang valid }}{\text { (Riduwan, 2015) }}$

Tabel 2. Kriteria Penilaian Hasil Uji Keterbacaan

\begin{tabular}{cc}
\hline Persentase & Kriteria \\
\hline $81-100$ & Sangat Layak \\
$61-80$ & Layak \\
$41-60$ & Kurang Layak \\
$21-40$ & Tidak layak \\
\hline & (Riduwan, 2015).
\end{tabular}

Berdasarkan hasil validasi dari validator, maka desain LKPD yang disusun dinyatakan dapat dijadikan sebagai bahan ajar untuk materi keanekaragaman hayati. Hasil validasi LKPD oleh validator dapat dilihat pada Tabel 3 :

\section{HASIL DAN PEMBAHASAN}

Tabel 3. Hasil Validasi LKPD Pengembangan Tumbuhan Obat

\begin{tabular}{cccc}
\hline No & Validator LKPD & Presentase & Kriteria \\
\hline 1 & Dosen pendidikan biologi & $88 \%$ & Sangat Valid \\
2 & Guru biologi 1 & $93 \%$ & Sangat Valid \\
3 & Guru biologi 2 & $95 \%$ & Sangat Valid \\
& Rata-rata & $92 \%$ & Sangat Valid \\
\hline & & Namun ada beberapa poin yang perlu \\
& Dari hasil validasi oleh tiga orang & diperbaiki sesuai saran validator, dapat \\
validator dapat diketahui bahwa desain & dilihat pada Tabel 4. Perbandingan LKPD \\
LKPD yang disusun ini dinilai sangat valid & sebelum divalidasi dan setelah divalidasi \\
dengan nilai rata-rata 92\% yang meliputi & dapat dilihat pada Gambar 1a, 1b dan 1c:
\end{tabular}

aspek materi, media dan kebahasaan.

Tabel 4. Saran dan Perbaikan LKPD

\begin{tabular}{|c|c|c|}
\hline No & Validator LKPD & Saran \\
\hline 1 & Dosen Pendidikan Biologi & $\begin{array}{l}\text { - Perbaiki penulisan penyakit pada LKPD, hendaknya } \\
\text { penyakit yang ditulis menggunakan bahasa yang } \\
\text { baku. }\end{array}$ \\
\hline 2 & Guru Biologi 1 & $\begin{array}{l}\text { - Perbaiki deskripsi gambar akar yang belum jelas } \\
\text { - Perbaiki susunan gambar }\end{array}$ \\
\hline 3 & Guru Biologi 2 & $\begin{array}{l}\text { Perbaiki kalimat pertanyaan yang masih } \\
\text { membingungkan siswa }\end{array}$ \\
\hline
\end{tabular}

Berdasarkan hasil analisis uji keterbacaan tersebut, diperoleh skor hasil uji keterbacaan LKPD oleh peserta didik sebesar $95 \%$. Dari persentase tersebut, maka LKPD berdasarkan studi tanaman obat ini dapat dikatakan layak untuk diuji cobakan pada peseta didik kelas X SMAN 09 Rejang Lebong. Hal tersebut karena hasil validasi yang telah mendapatkan katagori sangat valid dari aspek materi, media, dan kebahasaan. Beberapa penelitian juga menunjukan bahwa LKPD dengan katagori valid mampu memberikan sesuatu yang baru bagi siswa (Uniati dkk, 2018; Fajri, dkk 2018). 


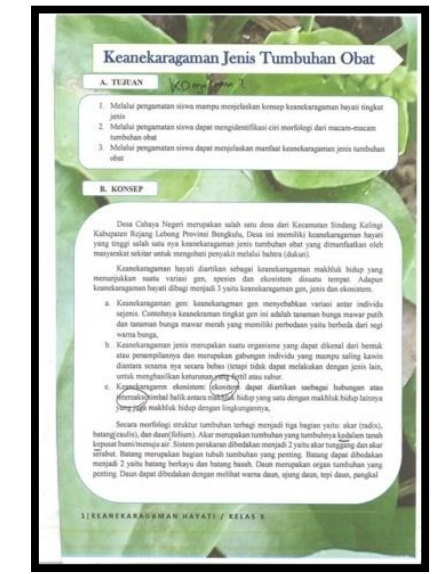

Gambar 1a. Sebelum divalidasi

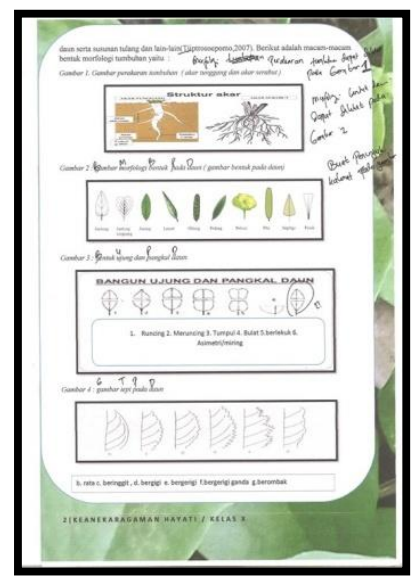

Gambar 1b. Sebelum divalidasi

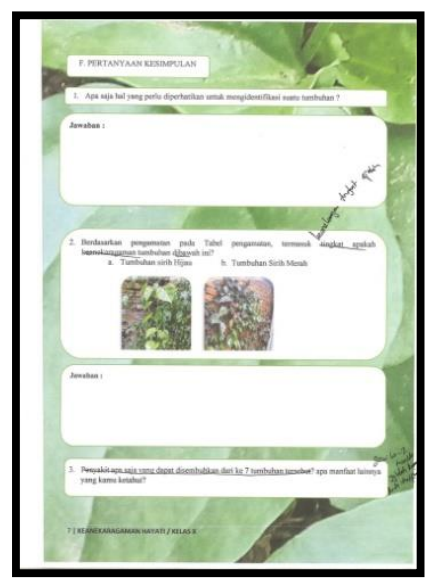

Gambar 1c. Sebelum divalidasi

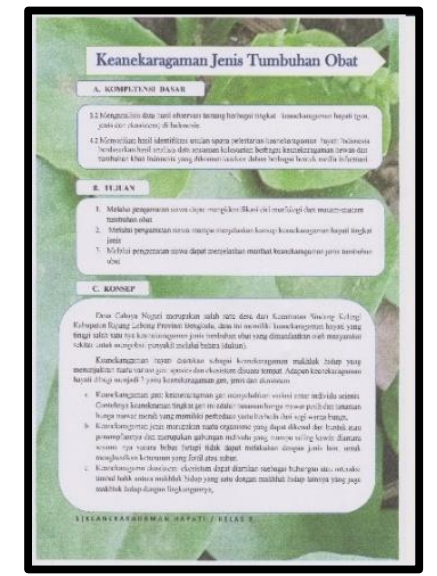

Gambar 1a. Setelah divalidasi

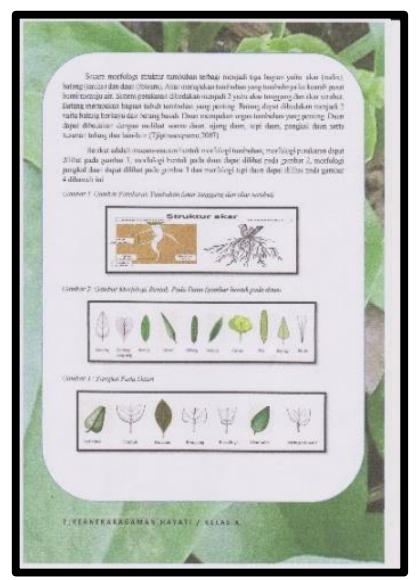

Gambar 1b. Setelah divalidasi

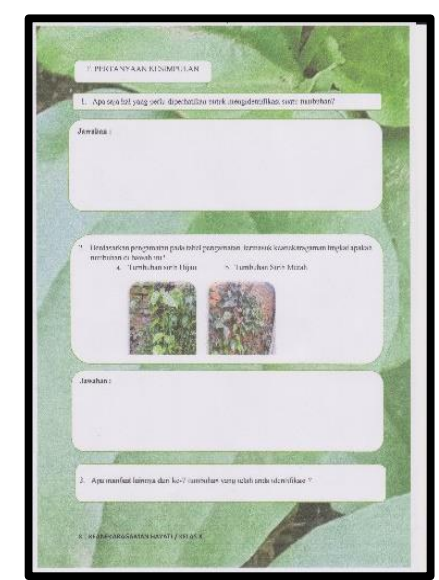

Gambar 1c. Setelah divalidasi 
Handini (2018) juga menyatakan bahwa bahan ajar yang berorientasi pada karakteristik dan kearifan lokal suatu daerah lebih memberikan kesan yang nyata dalam pembelajaran sehingga peserta didik mudah memahami materi yang dipelajari. Begitu juga menurut Tivani (2016) yang menyatakan bahwa permasalahan yang diangkat dalam pembelajaran harus berasal dari permasalahan nyata yang dihadapi peserta didik.

Adapun aspek yang dinilai dalam uji keterbacaan yang dikerjakan peserta didik yaitu meliputi aspek materi yaitu: (1). materi yang dilakukan mudah dipahami, materi pada LKPD menarik untuk dibaca, (2). Aspek Bahasa: Bahasa yang digunakan pada LKPD mudah dimengerti, huruf yang digunakan pada LKPD sederhana dan mudah dibaca, kalimat yang digunakan pada LKPD efektif (3). Aspek penyajian: judul dan tujuan LKPD mudah dipahami, penyajian materi pada LKPD mendorong rasa keingintahuan, penyajian materi pada LKPD mendorong untuk lebih membaca, pertanyaan-pertanyaan pada LKPD mudah dipahami, (4). Aspek kegrafikan: tampilan desain cover atau sampul depan menarik, penyajian tabel dan warna pada LKPD menarik, kualitas cetak gambar dan tulisan jelas dan baik.

Selain itu pengembangan bahan ajar dalam bentuk LKPD mengenai identifikasi tanaman obat pada Desa Cahaya Negeri Rejang Lebong ini dapat mendorong peserta aktif dalam proses pembelajaran. LKPD ini menuntut peserta didik untuk bekerja sendiri. Hal ini sesuai dengan Sujarwo (2013) dan Syah (2011) penggunaan bahan ajar dalam bentuk LKPD dapat menunjang keaktifan peserta didik dalam kegiatan pembelajaran secara lebih optimal. Hasil penelitian Listari dkk (2019) menyatakan bahwa proses pembelajaran dengan mengajak peserta didik mengamati jenis tanaman obat akan mempengaruhi hasil belajar peserta didik.

\section{PENUTUP}

Simpulan

LKPD yang dikembangkan berdasarkan penelitian tumbuhan obat di desa Cahaya Negeri mendapatkan nilai rata-rata $92 \%$ dari validator (kriteria sangat valid). Sedangkan hasil uji keterbacaan mendapatkan nilai rata-rata sebesar 95\%. Sehingga dapat disimpulkan bahwa LKPD berdasarkan identifikasi tumbuhan obat Desa Cahaya Negeri Kabupaten Rejang valid dan layak digunakan dalam pembelajaran Biologi materi Keanekaragaman Hayati.

\section{Saran}

1. Sebaiknya ada penelitian lebih lanjut di berbagai desa lainnya yang terdapat di Kecamatan Sindang Kelingi.

2. Sebaiknya dilakukan uji efektivitas sehingga dapat mengetahui lebih lanjut keefektifan dari LKPD dalam meningkatkan hasil belajar siswa.

\section{DAFTAR PUSTAKA}

Fajri, Aziza. 2018. Pengembangan Lembar Kerja Peserta Didik Materi Vertebrata Kelas X Berdasarkan Inventarisasi Ikan Laut. Diklabio: Jurnal Pendidikan dan Pembelajaran Biologi. 2 (2) : 5257.

Handini, M.N. 2018. Studi Etnobotani Tumbuhan Obat Suku Serawai Sebagai Pengembangan Handout Biologi Kelas X SMA. Diklabio: Jurnal Pendidikan dan Pembelajarn Biologi2 (2) : 35-43. (Online).

Herbie, Tandi. 2015. Kitab Tanaman Berkhasiat Obat-226 Tumbuhan Obat untuk Penyembuhan Penyakit dan Kebugaran Tubuh. Yogyakarta: Octopus Publishing House. 
Hidayat,R.S dan Napitupulu, R. M .2008.Kitab Tumbuhan Obat. Jakarta:Agriflo.

Kumalasari, L.O.R.( 2006). Pemanfaatan Obat Tradisional dengan Pertimbangan Manfaat dan Keamanannya. Majalah IImu Kefarmasian. 111 (1): 01-07.

Listari, Monica Descika,. Yani, Ariefa Primair,. dan Yennita. 2019. Implementasi LKPD Berdasarkan Eksplorasi Tanaman Obat Suku Pekal di SMA 8 Kota Bengkulu. Diklabio: Jurnal Pendidikan dan Pembelajaran Biologi. Vol 3(1) : 18. (Online).

Majid,Abdul.2009.

Perencanaan Pembelajaran .Bandung:PT Remaja Rosdakarya.

Prastowo,Andi.2011.Panduan Kreatif Membuat Bahan Ajar Inovatif. Yogyakarta: Diva Press.

Riduwan. 2015. Skala Pengukuran Variabel-variabel Penelitian. Bandung: Alfabeta.

Sugyono, 2012.Metode Penelitian Pendekatan Kuantitatif Kualitatif dan R\&D. Bandung: Alfabeta.

Suwarjo.2013. Pemanfaatan Media Pembelajaran Berbasis Lingkungan. Yogyakarta: UNY.

Situmorang, Toberni S.Dkk,(2018). Raya Huluan Kabupaten Simalungun Study the Utilization of Medicinal Plants in Ethnic Communities Simalungun in Raya Village Raya Bayu and Raya. Vol 4(2).

Syah, Muhibbin. 2011. Psikologi Belajar. Jakarta: Rajawali Pers.

Tivani, I., Paidi. 2016. Pengembangan LKS Biologi Berbasis Masalah untuk Meningkatkan Kemampuan Pemecahan Masalah dan Karakter Peduli Lingkungan. Jurnal Inovasi Pendidikan 2(1): 35-45.). Diakses 20 Juli 2019.
Uniati, Orin,. Jumiarni Dewi,. Yani, Ariefa Primair. 2018. Pengembangan Lembar Kerja Peserta Didik Berdasarkan Keragaman Jenis Tanaman di Green Chemistry Dan Kebun Biologi Universitas Bengkulu Univesitas Bengkulu. Diklabio: Jurnal Pendidikan dan Pembelajaran Biologi. Vol 3(1) : 18. (Online). 